\title{
DO NATIONAL BORDERS MATTER FOR QUEBEC'S TRADE?
}

John F. Helliwell

Working Paper No. 5215

\section{NATIONAL BUREAU OF ECONOMIC RESEARCH 1050 Massachusetts Avenue \\ Cambridge, MA 02138 \\ August 1995}

I am very grateful for the research collaboration of John McCallum, the research assistance of Julie Chu and Ross McKitrick, and research support from the Social Sciences and Humanities Research Council of Canada. Jim Nightingale and Philip Cross of Statistics Canada have been helpful in providing access to and understanding of the latest provincial trade and output data. An earlier version of this paper was presented at the Annual Meetings of the Canadian Economics Association, Université du Québec à Montreal, June 2, 1995. In revising the paper, I have been aided by helpful suggestions from many, including especially Bob Allen, Paul Beaudry, Mick Devereux, Erwin Diewert, Marc Duhamel, Manfred Keil, and Phil Neher. This paper is part of NBER's research programs in International Finance and Macroeconomics, and International Trade and Investment. Any opinions expressed are those of the author and not those of the National Bureau of Economic Research.

(C) 1995 by John F. Helliwell. All rights reserved. Short sections of text, not to exceed two paragraphs, may be quoted without explicit permission provided that full credit, including $\odot$ notice, is given to the source. 


\title{
DO NATIONAL BORDERS MATTER FOR QUEBEC'S TRADE?
}

\begin{abstract}
Extending McCallum's (1995) result, based on a gravity model of 1988 trade flows, that a typical Canadian province trades 22 times more with other provinces than with U.S. states of similar size and distance, this paper asks how Quebec trade patterns compare with those of other provinces. The results, based on revised data for 1988,1989 and 1990 , show that while the typical province trades more than 20 times as much with other provinces as with comparable U.S. states, for Quebec the multiple is even greater. Thus trade between Quebec and the United States appears to be an even less viable alternative to interprovincial trade for Quebec than it is for the rest of Canada. The implications of these results for international economics are considerable, as they show that trade linkages within a national economy are far greater than previously imagined. If these results are confirmed, they imply that the fabric of national economies is far tighter than that of the global trading system, even for countries operating without substantial trade barriers.
\end{abstract}

John F. Helliwell

Department of Economics

University of British Columbia

Vancouver BC V6T 1Z1

CANADA

and NBER 


\section{INTRODUCTION}

Growing trade and capital mobility, and much talk of globalization, may have created the impression that national boundaries no longer matter much for trade and capital movements. John McCallum (1995) has compared trade flows among Canadian provinces with those between Canadian provinces and U.S. states, making use of a gravity model in which trade is determined primarily by the economic size of the trading partners and the distance between them, to calculate that Canadian provinces trade about 20 times as much with each other as with U.S. states of a similar size and distance. Thus the trade-generating powers of the Canadian federation are more than an order of magnitude larger than those of the European Union ${ }^{1}$.

These new results are important, as they challenge many of the presumptions often made about the relative importance of international and interprovincial trade, and about the ability of trade flows to arbitrage away international price differences. Survey results presented in this paper show that experts and non-experts alike think that trade between provinces and trade between provinces and states tend to be fairly similar in magnitude, after adjusting for the effects of distance and market size. The median respondent estimated that the factor of 20 quoted above was actually less than 1.0. Even those who thought interprovincial trade to be more active than trade from Canadian provinces to U.S. states usually guessed the extent to be between 1.0 and 1.4 , more than an order of magnitude below our latest estimates presented in the next section. The vast difference between perceived and measured differences between interprovincial and international trade linkages emphasizes the potential importance of the new results, if it is fair to treat the impact of an empirical finding to be a product of how dramatically it differs from received opinion and the strength of the evidence on which it is based. If the McCallum results are confirmed, they also have important implications for the assessment of the economic effects of Quebec separation. If national boundaries are such an important determinant of trade, the

${ }^{1}$ Frankel and Wei (1993) estimate that trade flows among the countries of the European Union are 1.68 times as large as than those between EU countries and non-EU countries, after using a gravity model to allow for the effects of size and distance. 
ability to maintain the existing trade linkages with the rest of Canada after separation becomes both more important and less likely. Similarly, if interprovincial trade is so much more important than international trade, it is less easy to assume that expanded trade with the United States can be used to replace interprovincial trade now taking place.

This paper attempts to assess the importance of this new research for Quebec by first updating and extending McCallum's analysis to make use of revised and additional data. We then examine the extent to which Quebec's interprovincial and U.S. trade patterns support the revised national results. The paper then asks how these results could have been so completely unexpected, and tries to place them in the context of other studies of the differences between national and global markets. Finally, some attempt is made to assess the implications that the tightness of interprovincial trade linkages might have for the economics of Quebec independence.

\section{REVISED AND EXTENDED NATIONAL RESULTS}

The basic explanatory equation used by McCallum (1995) embodies the long-established gravity model of trade, wherein trade flows from an exporting region $i$ to an importing region $j$ are a loglinear function of real GDPs in the two regions and the distance between them:

(1) $\ln S_{i j}=\alpha_{0}+\alpha_{1} \operatorname{lnGDPX}+\alpha_{2} \operatorname{lnGDPM}+\alpha_{3} \ln ($ dist $)+\epsilon_{\mathrm{ij}}$

where, in the present application, shipments ( $\mathrm{S}_{\mathrm{ij}}$ ), and the GDPs of exporters (GDPX) and importers (GDPM) are measured in million Canadian dollars ${ }^{2}$, distance is measured in miles between the principal cities in the respective states and provinces, and the error term $\epsilon_{i j}$ is

${ }^{2}$ Purchasing power parities for GDP, taken from version 5.6 of the Penn World Table (Summers and Heston 1991) are used to convert U.S. state GDPs to Canadian dollars. In McCallum (1995) an exchange rate of 85 \$US/\$C was used to convert provincial GDPs to US dollars, and the state GDPs were left in their original published form. Here we use PPPs, in terms of $\$ C / \$$ US, of $1.2090,1.2087$, and 1.2074 for 1988, 1989, and 1990 . 
assumed to be normally distributed. This gravity model of trade is an example of a longestablished empirical regularity (Tinbergen 1962, Linneman 1966) that had no ready derivation from the standard Heckscher-Ohlin model of comparative advantage that dominated trade theory at the time. In the last fifteen years, however, there has been an outpouring of trade theory that includes one or more forms of product differentiation or market segmentation, often in the context of some type of increasing returns to scale. Helpman (1984) surveys some of the models, and shows how differentiated products give rise to the gravity equation as the predictor for bilateral trade flows.

Table 1 reports the latest results, using data for 1988,1989 and 1990 to estimate separate equations for each year, and then to estimate a system of three equations using an iterative version of Zellner's SUR with the coefficients restricted to be the same in all years. As shown at the bottom of the equation, the probability of the restrictions being appropriate is rather low, reflecting the combined effect of fairly small differences in rather precisely estimated coefficients. The new equation for 1988 differs slightly from that of McCallum, mainly because of revisions to the shipments data for 1988, and to our current use of shipment for total goods rather than the slightly smaller manufacturing-plus-primary aggregate used by McCallum. The latest 1988 estimate of interprovincial trade as a multiple of province-state trade is 20.5 (calculated as the antilog of 3.02), compared to McCallum's original estimate of 22. The estimated trade multiple for 1989 is 18.5 , while that for 1990 is 24.8 . When data for all three years are combined, the estimated border effect is 20.9. The surprising feature of the latest results is that the estimated border effect rises from 1989 to 1990, while aggregate trade data presented in Helliwell and McCallum (1995, chart 2) show east-west trade falling in relation to north-south trade in and after 1990. Disaggregated tests reported in Table 3 show that the border effect rose from 1989 to 1990 in all provinces except for New Brunswick, where it was essentially unchanged. The interprovincial trade apparently grew faster, or fell less fast, than trade with US states, especially trade with smaller or more distant states. 


\section{IS QUEBEC'S TRADE DIFFERENT?}

Table 2 shows the effect of adding separate variables for covering first Quebec's trade with the thirty U.S. states (QUUS) in the study, and then Quebec's interprovincial trade (QUC). If Quebec's trading relations with U.S. states are stronger than those between other provinces and the U.S. states, then QUUS would take a positive sign. Similarly, if Quebec's trading links with other provinces are stronger than those among the anglophone provinces, then QUC will take a positive sign. The results show that Quebec's imports from and exports ${ }^{3}$ to the thirty U.S. states are significantly below those of the other provinces. Quebec's interprovincial trade is also less than for the other provinces, but this difference is half as large and is not significant. If we add these Quebec effects to the national border effect, we can ask for Quebec the analogous question to that asked by McCallum for the country as a whole: How large is Quebec's trade with other provinces, compared to that with U.S. states, after adjusting for the effects of size and distance? The answer for Quebec is 26.0 if we include both the significant U.S. effect and the insignificant Canadian effect $(26.0$ is $\exp (3.06+.37-.17))$. This suggests Quebec's trading links with the rest of Canada, relative to those with the United States, are even stronger than in other provinces.

An alternative way of seeing whether the national results apply equally to Quebec is to estimate the gravity model with common coefficients for economic size and distance, but separate border variables for each province and year. The results are shown in Table 3 . The first three columns show the border effects from a system in which separate border effects are allowed for each year, while the fourth column shows the results if the border effects are permitted to vary by province but not by year. The final column shows the results if a separate variable is adding covering all of Quebec's trade, to reflect the fact, already evident from Table 2, that Quebec has less internal and external trade than other provinces. For each province, the border coefficient is strongly significant. If a system is estimated in which border effects are estimated separately for Quebec and for the other provinces as a group, but otherwise like the

${ }^{3}$ The effects on imports and exports are identical, since splitting QUUS into separate variables for imports and exports produces identical values for the two coefficients. 
final column of Table 3, the estimated border effect for Quebec is 31.8 ( =exp(3.46)), compared to $19.9(=\exp (2.99)$ for the other provinces. This difference is significant only at the $25 \%$ level. The evidence from all three years, treated separately or together, suggests that national borders matter even more for Quebec than for the rest of Canada.

\section{HOW SURPRISING ARE THESE RESULTS?}

To get some flavour of what we might expect to find from this research, we need to remind ourselves that Canada and the United States are on either side of the world's largest bilateral trading flows. The two countries share an enormous land mass divided by a border that is part easily navigable water and part an unmarked line that cuts the continental divide almost at right angles. The tariffs and other border limitations to trade and capital movements are and have long been lower than almost anywhere in the world, and Canada has the largest degree of foreign ownership among any of the industrial countries, with the United States being by far the largest source country. If ever one would expect to find a national border that had relatively little effect on trade and capital movements, it would be the line between Canada and the United States. There has also been much talk about interprovincial trade barriers, which have been the focus of occasional spats and frequent meetings, with some estimates of their aggregate cost being as high as $1 \%$ of GDP 4 .

When this information is combined with the fact that much of what we eat, especially in the winter, is trucked in from California, it is not so surprising that surveys we have taken uniformly show no premonition of the results shown in Tables 1 and 2 . When asked to estimate how much trade Canadian provinces do with each other, in comparison to how much they trade with U.S. states of similar economic size and at a similar distance, almost

${ }^{4}$ Desmond Morton reminded the UBC Quebec/Canada conference in March 1995, where some of these results were presented, that it was concern about interprovincial trade barriers, and other impediments to a smoothly functioning national economy, that apparently finally decided Jacques Parizeau, in the course of travel to a meeting in Banff, that Canada could not be made to work satisfactorily, and that Quebec would be better off on its own. 
everyone, as shown by Figure 1 , gives an estimate falling in the range between 0.6 times and 1.4 times, with the median answer being below 1.0. That is, some think that trade linkages among the provinces are slightly tighter than are the trade linkages between the Canadian provinces and U.S. states, and some think that they are slightly weaker, with the range of answers being fairly narrow.

But the best estimate of the number is not 0.7 or 1.3 , or anything even remotely close. Our current best estimate is $\mathbf{2 0 . 9}$ for Canada as a whole and more for Quebec. Figure 1 juxtaposes the frequency distribution of the survey responses with the estimated distribution of the national effect based on equation (iv) in Table 1. The distributions have almost no overlap, so that if we ask whether the statistical results can come from the same realm as our prior notions, the answer is surely not ${ }^{5}$. Unless there are some very large errors lurking in the measurement or modelling of interprovincial and international trade data, our longstanding impressions about the tightness of the economic union have been wildly far off the mark. Many different tests have been run to make sure that the results are not due to any specific regions, products, or assumptions about the determinants of the trade flows. As was done in McCallum (1995), we tested to make sure that the results did not change under instrumental variables estimation, and with weighted regression based on the geometric mean of trading partner GDPs. Additional tests have shown that trade flows are slightly better explained if the gravity model uses population and per capita GDP separately for importing states or provinces, but this does not change the border effects. We have been told that there is a risk that some of the measured bilateral trade flows from provinces to border states are then directed to other states. This was tested for by first allowing for adjacency effects in general, and then asking if there were additional trade flows from provinces to border states

${ }^{5}$ More precisely, if we compare the distributions of the survey responses quoted above with the distribution of the antilogs of the estimated coefficient on the border variable, the zvalue of the difference of the means is 57 . This may be compared to a critical value, with a confidence limit of one-ten-millionth of $1 \%$, of 6 . Thus there is thus much less than one chance in a billion that the two distributions have the same means. Alternative tests provide similarly striking confirmation that the two distributions shown in Figure 1 are different. 
beyond those that could be explained by adjacency, GDP and distance. We found such an additional effect, of slight statistical significance, but it had no impact on the estimated border effect. To further examine the possible sources and structure of the strong interprovincial trade linkages, we considered the hypothesis that there are economies of scale in importation, with products from the United States being shipped to Ontario for subsequent distribution to the other provinces. To test for this a variable was constructed taking the value of 1.0 for all trade flows from U.S. states to Ontario and for all shipments from Ontario to other provinces. If this distribution channel is an important part of the story, we would expect to find a significant positive coefficient on the variable and a consequential drop in the estimated border effect. However, the variable took an insignificant negative coefficient, and there was no change in the estimated border effect.

Weighted regression using the geometric mean of GDPs did not alter the results, but weighted regression using shipments data themselves as the weights reduces the coefficients on the border variable sharply, from about 3.0 to about 2.2. This is what one would expect, since the largest trade flows are among the states and provinces heavily involved in the auto industry, which makes up a substantial part of total goods trade, and where a high level of industry integration has existed for many years. However, it is also important to remember that separate estimation for each province using unweighted data shows Ontario and Quebec to have higher-than-average border effects.

Although further NAFTA-induced integration of North American businesses may in future increase the relative size of North-South flows, there is nothing by way of data changes, either through revision or changes in the next decade, that seems likely to allow beliefs such as those reported in our survey to be maintained. We have been trying to think of any empirical result we have ever seen that seemed to be both solid and vastly far removed from both expert and popular opinion. We have been unable to think of anything even remotely close.

There are now four essential lines of thought to follow. One is to ask why it is that 
trade linkages within the country are so much more pervasive than those between countries. A second to ask why it can have been, if the result stands up to scrutiny, that we were all so wrong in our previous impressions. A third is to ask what downward trends are likely to occur in our estimated border effects when and if interprovincial trade date become available for the 1990s, and to assess the less complete data for trade in services. A final and more speculative question is ask what might be the implications for the future of Canada and Quebec, under alternative assumptions about the results of the Quebec referendum.

Starting with the first question, we have gone back to some of the related literature in international economics to see if there are any straws in the wind that might help to reveal from a different perspective the relative strength of interprovincial and international linkages. One useful recent study is by Engel and Rogers (1994), who have studied the variability of prices among cities in the United States and Canada, with allowance for distance and a border effect. They found a very strong border effect, and calculated the implicit width of the border as something on the order of 2500 miles. The border width can be calculated using similar procedures in the case of the study of trade flows described above, and it is of the same order of magnitude.

We also went back and reread the literature surrounding an important but controversial paper by Feldstein and Horioka (1980), presented first more than fifteen years ago as a Mackintosh Lecture at Queen's University. They found that national savings and investment rates were highly correlated, which they took to imply that international capital markets were not anything like as tightly integrated as everyone had assumed. Many argued that their results could be consistent with high capital mobility, but many tests since have gradually led researchers to treat their evidence as being consistent with a number of other results suggesting much less than fully integrated international capital markets. If the Feldstein/Horioka interpretation of the cross-country results is correct, and if our new results about the tightness of the Canadian economic union are correct, we should expect to find that correlations of savings and investment rates across provinces are far lower than across countries, since at least within the country we would expect to find banks and other 
institutions shipping funds from savers to investors without requiring the saving and the investment to take place in the same piece of geography. Putting together the relevant data for the Canadian provinces, we were struck afresh by the size of the interprovincial transfers in this country, as well as well as the extent to which private savings appear to flow from one region to another, thus breaking any linkage between savings rates and investment rates on a province-by-province basis ${ }^{6}$. Bayoumi and Klein (1995) use the provincial trade balance data to test the compare interprovincial and international capital mobility, employing a somewhat different specification than Feldstein and Horioka, and conclude that capital mobility is much higher among provinces than between Canada and other countries.

Thus there is some evidence of different types supporting the idea that the economic linkages within a nation are much tighter than those between nations. But why? The answers are likely to lie in a whole mix of educational, cultural, historical, political, associational, emotional, and geographical ties based on migration and family ties, and supported by networks of transportation, communication, and education, along with the cherished portability of health care and pension rights, if not completely of beer.

Turning to the second question, as to how such an important fact, if it is that, could have been there in front of us without being spotted, we have thought of two possible answers, and are looking for more. One reason is that in the world as a whole there are almost no measures of trade flows within a country, and the Statistics Canada data are probably unique. Only in a federation are there likely to be serious efforts to put together accounts for the provincial economies, and only with Statistics Canada is such a job likely to be done on as complete and thorough a basis. In addition, only since 1988 have the Canadian international trade statistics been expanded to included exports and imports to and from each province and each U.S. state. When McCallum did his first estimates, there was only one

${ }^{6}$ Brown (1992, especially Figures B-1 and B-2) compares the international and interprovincial correlations between savings and investment, and shows that the correlations apparent among countries do not appear among the provinces. There are similar results, using less complete data, for US states (Sinn (1992) and for Japanese regions (Dekle 1995). 
year, 1988, for which both the interprovincial and international shipments data were available to permit the model of trade flows among provinces, and between provinces and states, to be estimated. Even now, there are only three years of data available, so the possibility for the research to be done is relatively recent. The data for subsequent years will apparently not be forthcoming at all unless funds are found to undertake the necessary surveys.

A second reason for perceptions to diverge from the new results is that there are trade data published showing international trade to be large and growing, and showing international trade to be larger than interprovincial shipments for a number of provinces. Data drawn from the provincial accounts, and reported in Helliwell and McCallum (1995) show international shipments of goods rising faster than interprovincial shipments from 1990 through $1993^{7}$. Since there are no post-1990 direct measures of interprovincial trade data, the subsequent interprovincial trade flows are based on the assumption that total interprovincial exports grow at the same rate as domestic final demand, and are allocated among importing provinces, on a commodity-by-commodity basis for 300 commodities, according to the 1990 exports from each province to each other province. The directly measured data for foreign trade should sharp increases since 1990, while the method used to estimate interprovincial trade has it growing in line with domestic final demand, which was sluggish during the 1990s.

What is likely to happen to our estimates of the border effect when data are available for the 1990s? The sharp growth in international trade suggests that we might expect a downward trend to emerge during the 1990s. However, our results for 1990 caution a waitand-see attitude, since the aggregate data can mask different patterns of the component flows. We also need to consider also whether the approximations used in the provincial accounts are likely to be confirmed by subsequent direct estimation. The current series for the 1990s are likely to be underestimates of directly measured flows if there are substantial interprovincial

${ }^{7}$ The ratio of interprovincial to international trade in services is always much higher than for goods, and shows no downward trend in the 1990s. The ratios are shown separately for goods and services in Helliwell and McCallum (1995). 
trade flows associated with international trade (exports were growing faster than domestic demand in the early 1990s) or if there are trend increases in interprovincial trade for some of the same reasons that international trade has grown relative to world GDP. Even the directly estimated numbers, if available, would be likely to show interprovincial trade growing less fast than trade with U.S. states in the early 1990s. One reason for this is that foreign demand has risen faster than domestic demand for cyclical reasons, with Canada facing a larger recession than that in the United States. However, the cyclical increase in exports would be offset in part or whole, by the cyclical reduction in imports, so the net foreign trade volume of the cyclical asymmetry is not certain. Second, there is ample evidence of post-NAFTA increases in trade with the United States. This may entail some facilitating expansions of interprovincial trade, while some may be in substitute for interprovincial shipments. The net NAFTA effect is likely to be to increase province-state trade relative to province-to-province trade. However, there seems to be little likelihood that any 1990 s data are likely to give mid1990s estimate of the border effect that are less than fifteen for merchandise trade, and much more for services, for either Canada or Quebec.

Returning to the question of how these results should be so surprising, perhaps it was necessary to assemble the data and estimate a model that explicitly allows for size and distance to force us to accept the full implications of what we already knew: that from a geographic point of view the Canadian economy is a very thin rectangle perched on top of the much deeper U.S. economy. Indeed, the geography of the Great Lakes ensures that perhaps a majority of Canadian employment and output takes place below the 49th parallel.

The final question relates to the implications of the new results for the economic futures of Canada and Quebec, and for the results and implications of Quebec referendum. There could hardly be a fact of more potential importance to the referendum decision. The results show that Quebec is even more tightly tied in to the fabric of Canada, relative to its ties to the United States, than are the anglophone provinces. One comforting line of thinking about separation is based on the idea that Quebec already has equally close trading ties with the ROC and the United States, so that there could not be much at stake in moving from 
treating the ROC as other provinces to another country. But, as we have argued, this premise is false by a factor of more than twenty.

The central point is that the fabric of the Canadian economic union is much tighter and more closely woven than anyone had previously believed. This implies that it would be no trivial matter, for either Quebec or the remaining parts of Canada, if Quebec were to change from being part of Canada to being an independent country. Since the discovery of the relative tightness of the economic union is relatively recent, we still do not have a full understanding of what makes the economic linkages among provinces so much stronger than those with the United States. Thus it is not easy to tell which of these factors would be most likely to be put at risk if Quebec became an independent country. But it is clear that Canadians have put together a much tighter economic federation than anyone believed, so that there is much more to lose than anyone would have guessed if the country were to be split. As shown by the gap between the survey results and the new evidence, there is a vast gulf between perception and reality; this paper has been a small attempt to fill the gap. 


\section{REFERENCES}

Bayoumi, T. and M.W. Klein (1995) "A Provincial View of Capital Mobility." NBER Working Paper No. 5115 (Cambridge: National Bureau of Economic Research).

Brown, D.M. (1992) "Efficiency, Capital Mobility and the Economic Union." In D.M. Brown, F. Lazar, and D. Schwanen, Free to Move: Strengthening the Economic Union. (Toronto: C.D. Howe Institute) 38-98.

Dekle, R. (1995) "Savings-Investment Associations and Capital Mobility: On the Evidence from Japanese Regional Data." International Finance Discussion Papers No. 496 (Washington: Board of Governors of the Federal Reserve System)

Engel, C., and J.H. Rogers (1994) "How Wide is the Border?" NBER Working Paper No. 4829 (Cambridge: National Bureau of Economic Research)

Feldstein, M., and C. Horioka (1980) "Domestic Saving and International Capital Flows." Economic Journal 90 (June 1980): 314-29.

Frankel, J. and S.-J. Wei (1993) "Trade Blocs and Currency Blocs." NBER Working Paper No. 4335. (Cambridge: National Bureau of Economic Research)

Helliwell, John F. and John McCallum (1995) "National Borders Still Matter for Trade." Policy Options/Options Politiques 16 (July/August 1995):44-8.

Helpman, E (1984) "Increasing Returns, Imperfect Markets, and Trade Theory." In R. Jones and P. Kenen, eds., Handbook of International Trade (Amsterdam: North-Holland) Volume 1, 325-65.

Linneman, H. (1966) An Econometric Study of International Trade Flows. (Amsterdam: NorthHolland).

McCallum, John (1995) "National Borders Matter: Canada-U.S. Regional Trade Patterns" American Economic Review 85 (June 1995): 615-23.

Sinn, S. (1992) "Savings-investment Correlations and Capital Mobility: On the Evidence From Annual Data." Economic Journal 102: 1162-70.

Summers, R. and A. Heston (1991) "The Penn World Table (Mark 5): An Expanded set of international comparisons, 1950-88." Quarterly Journal of Economics 106: 327-68. 
Table 1

Revised Estimates of the Effects of the Border on Trade Flows

\begin{tabular}{|c|c|c|c|c|}
\hline Equation & (i) & (ii) & (iii) & (iv) \\
\hline $\begin{array}{l}\text { No. of } \\
\text { Observations }\end{array}$ & 677 & 677 & 677 & $3 \times 677$ \\
\hline Estimation Method & OLS & OLS & OLS & SUR \\
\hline Dependent Variable & $\begin{array}{l}\ln (\text { ship) } \\
1988\end{array}$ & $\begin{array}{l}\ln (\text { ship) } \\
1989\end{array}$ & $\begin{array}{l}\ln (\text { ship) } \\
1990\end{array}$ & $\begin{array}{l}\ln \text { (ship) } \\
1988,1989,1990\end{array}$ \\
\hline Constant & $\begin{array}{l}-4.19 \\
(5.9)\end{array}$ & $\begin{array}{l}-4.06 \\
(5.6)\end{array}$ & $\begin{array}{l}-5.60 \\
(7.3)\end{array}$ & $\begin{array}{l}-4.30,-4.38,-4.54 \\
(6.5,6.6,6.8)\end{array}$ \\
\hline
\end{tabular}

Coefficients:

$\begin{array}{lllll}\text { InGDPX } & 1.18 & 1.19 & 1.23 & 1.19 \\ & (37.6) & (37.2) & (36.4) & (40.5) \\ \operatorname{lnGDPM} & 1.05 & 1.02 & 1.05 & 1.03 \\ & (33.6) & (32.5) & (31.4) & (35.3) \\ \ln (\text { dist }) & -1.41 & -1.41 & -1.33 & -1.39 \\ & (22.6) & (22.2) & (19.7) & (23.6) \\ \text { Cdummy } & 3.02 & 2.92 & 3.21 & 3.04 \\ & (23.2) & (22.1) & (22.9) & (24.9) \\ & & & & \\ \overline{\mathrm{R}}^{2} & .802 & .795 & .782 & .803, .796, .782 \\ \text { S.E.E. } & 1.10 & 1.12 & 1.19 & 1.10,1.12,1.18 \\ & & & & \text { P-value of restrictions }=.010 \\ \text { Border Effect } & 20.5 & 18.5 & 24.8 & 20.9\end{array}$

Notes: Absolute values of $t$ statistics are in parentheses. The dependent variable is the logarithn of total shipments of goods from province or state i to province or state $j$, with InGDPX being the logarithm of i's GDP and InGDPM of $j$ 's GDP. The data include province-to-province trade for ten provinces plus trade between each province and each of the thirty largest states. Observations with zero shipments in any of the three years (13 in total) are excluded. Cdummy takes the value 1 for each observation recording trade from one province to another. 
Table 2

Effects of the Border on Quebec Trade Flows

\begin{tabular}{|c|c|c|c|c|}
\hline $\begin{array}{l}\text { Equation } \\
\text { No. of }\end{array}$ & (i) & (ii) & (iii) & (iv) \\
\hline Observations & 677 & 677 & 677 & $3 \times 677$ \\
\hline Estimation Method & OLS & OLS & OLS & SUR \\
\hline Dependent Variable & $\begin{array}{l}\ln (\text { ship) } \\
1988\end{array}$ & $\begin{array}{l}\ln (\text { ship) } \\
1989\end{array}$ & $\begin{array}{l}\ln (\text { ship) } \\
1990\end{array}$ & $\begin{array}{l}\ln (\text { ship) } \\
1988,1989,1990\end{array}$ \\
\hline Constant & $\begin{array}{l}-4.36 \\
(6.1)\end{array}$ & $\begin{array}{l}-4.25 \\
(5.9)\end{array}$ & $\begin{array}{l}-5.81 \\
(7.6)\end{array}$ & $\begin{array}{l}-4.48,-4.56,-4.73 \\
(6.7,6.8,7.1)\end{array}$ \\
\hline $\begin{array}{l}\text { Coefficients: } \\
\text { lnGDPX }\end{array}$ & $\begin{array}{l}1.20 \\
(36.9)\end{array}$ & $\begin{array}{l}1.21 \\
(36.6)\end{array}$ & $\begin{array}{l}1.25 \\
(35.8)\end{array}$ & $\begin{array}{l}1.21 \\
(39.8)\end{array}$ \\
\hline InGDPM & $\begin{array}{l}1.08 \\
(33.0)\end{array}$ & $\begin{array}{l}1.04 \\
(32.0)\end{array}$ & $\begin{array}{l}1.07 \\
(30.9)\end{array}$ & $\begin{array}{l}1.05 \\
(34.9)\end{array}$ \\
\hline $\ln ($ dist $)$ & $\begin{array}{l}-1.44 \\
(22.7)\end{array}$ & $\begin{array}{l}-1.44 \\
(22.3)\end{array}$ & $\begin{array}{l}-1.36 \\
(19.9)\end{array}$ & $\begin{array}{l}-1.42 \\
(23.7)\end{array}$ \\
\hline Cdummy & $\begin{array}{l}3.03 \\
(21.0)\end{array}$ & $\begin{array}{l}2.96 \\
(20.1)\end{array}$ & $\begin{array}{l}3.24 \\
(20.8)\end{array}$ & $\begin{array}{l}3.06 \\
(22.6)\end{array}$ \\
\hline Quc & $\begin{array}{l}-.14 \\
(0.5)\end{array}$ & $\begin{array}{l}-.23 \\
(0.8)\end{array}$ & $\begin{array}{l}-.23 \\
(0.7)\end{array}$ & $\begin{array}{l}-.17 \\
(0.6)\end{array}$ \\
\hline Quus & $\begin{array}{l}-.38 \\
(2.4)\end{array}$ & $\begin{array}{l}-.37 \\
(2.3)\end{array}$ & $\begin{array}{l}-.42 \\
(2.4)\end{array}$ & $\begin{array}{l}-.37 \\
(2.4)\end{array}$ \\
\hline$\overline{\mathbf{R}}^{2}$ & .803 & .796 & .783 & $.805, .798 .784$ \\
\hline S.E.E. & 1.10 & 1.12 & 1.18 & $1.09,1.11,1.18$ \\
\hline Border Effect & 26.3 & 22.2 & 30.9 & $\begin{array}{l}26.0 \\
P \text { value of restrictions }=.054\end{array}$ \\
\hline
\end{tabular}

Notes: Absolute values of $t$ statistics are in parentheses. The dependent variable is the logarithn of total shipments of goods from province or state $i$ to province or state $j$, with InGDPX being the logarithm of i's GDP and lnGDPM of j's GDP. Quus is 1 for trade between Quebec and a state. Quc is 1 for Quebec's trade with another province. 
Table 3

Border Coefficients by Province and Year

1988

Newfoundland

2.01

(5.41)

1989

1990

1.98

(5.24)

2.59

(6.43)

2.60

(6.69)

(6.77)

2.97

(8.05)

New Brunswick

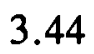

$(9.29)$

2.94

(7.81)

3.41

(9.04)

2.86

(7.65)

(8.51)

\subsection{7}

(9.15)

3.30

(8.80)

3.30

(8.82)

2.94

(7.13)

3.15

(7.86)

3.31

(8.23)

\subsection{1}

(8.06)

3.36

(8.43)

Manitoba

3.49

(8.76)

8.82

1988-90

(a)

(b)

1988-90

\subsection{9}

(6.21)

2.20

(6.28)

2.71

(7.44)

2.73

(7.53)

3.02

(8.63)

3.01

(8.63)

3.39

3.38

(9.65)

(9.67)

3.08

3.38

(8.88)

(9.16)

3.35

3.30

(9.61)

(9.48)

3.00

(8.16)

2.91

(7.78)

3.40

(9.78)

3.39

(9.80)

Saskatchewan

$$
3.18
$$

(8.68)

3.03

(8.12)

3.13

(7.85)

3.02

3.02

(8.68)

(8.71)

Alberta

$$
2.95
$$

2.84

(7.60)

3.42

(8.61)

3.21

(9.29)

3.20

(9.27)

British Columbia

$$
\text { (8.04) }
$$

2.88

(7.24)
2.90

(8.35)
2.88

(8.34)

Qutrade

$\overline{\mathrm{R}}^{2}$

.807

.800

.784

$-.34$

(2.29)

S.E.E.

1.09

1.11

1.18

$1.09,1.11,1.18 \quad 1.09 .1 .10,1.18$

Notes: Three systems are reported in the table, one in col. 1-3, and the others in cols. 4 and 5. The other coefficients, identical to four significant figures in the first two systems, are $1.176(t=37.4)$ on exporter GDP, $1.025(t=35.4)$ on importer GDP, and $-1.381(t=23.3)$ on distance. In the final column, they are $1.194(\mathrm{t}=36.9), 1.042(\mathrm{t}=35.1)$, and $-1.407(\mathrm{t}=23.4)$, respectively. 


\section{Fig 1 Internal vs External Trade Survey vs Model Estimates, 1988-90}

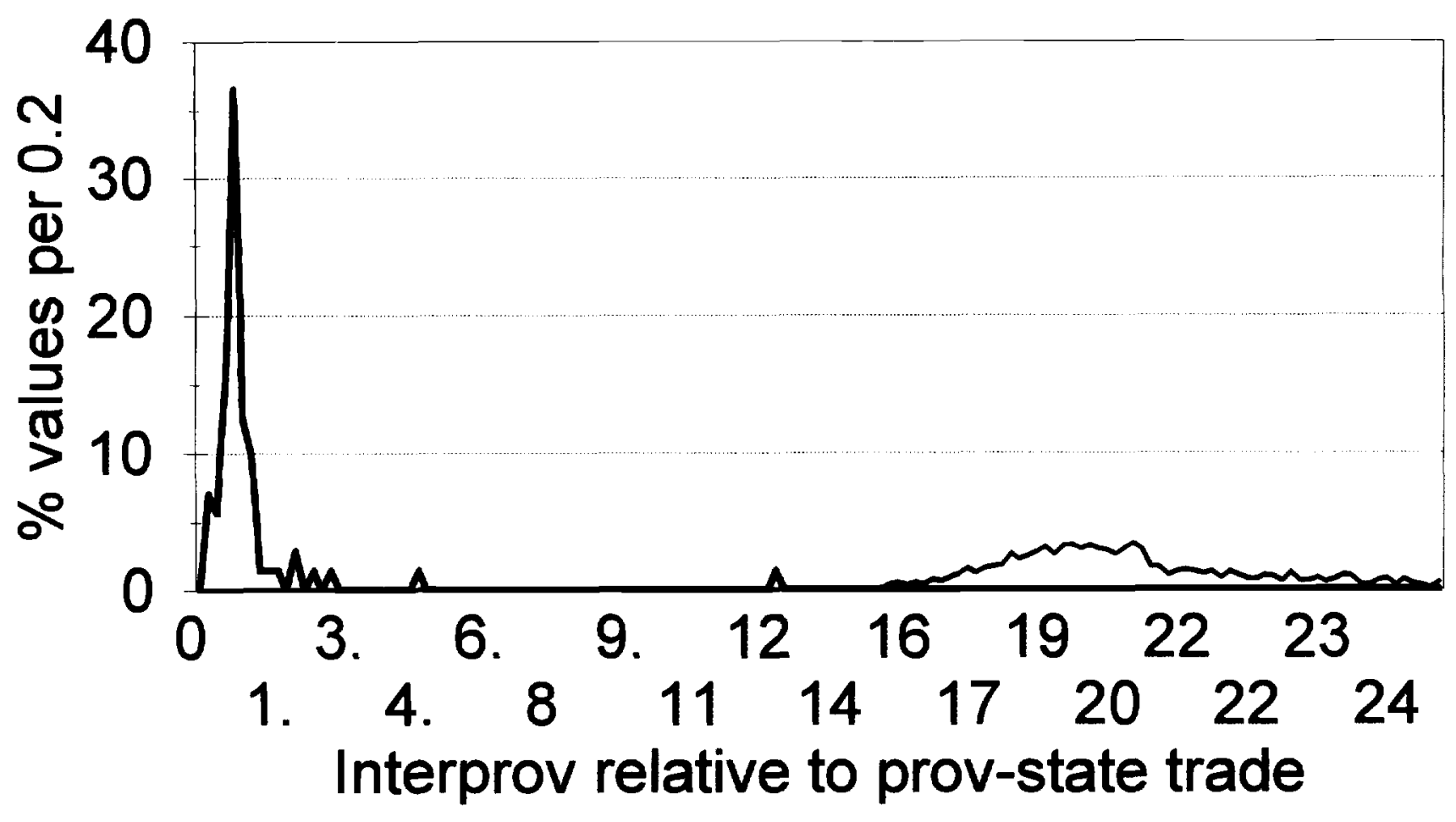

- Survey - Model 